\title{
Increasing temperatures, diversity loss and reorganization of deep-sea fish communities east of Greenland
}

\author{
Margrete Emblemsvåg ${ }^{1,2, *}$, Ismael Núñez-Riboni ${ }^{3}$, Helle Torp Christensen ${ }^{4}$, \\ Adriana Nogueira ${ }^{4}$, Agnes Gundersen ${ }^{1}$, Raul Primicerio ${ }^{2}$
}

${ }^{1}$ Møreforsking AS, 6009 Ålesund, Norway

${ }^{2}$ UiT, The Arctic University of Norway, 9037 Tromsø, Norway

${ }^{3}$ Thunen Institute of Sea Research, 27572 Bremerhaven, Germany

${ }^{4}$ Greenland Institute of Natural Resources, 3900 Nuuk, Greenland

\begin{abstract}
In recent years, Arctic and sub-Arctic fish communities have shown extensive reorganization on shelves and in shallow waters, but little is known about the ecological impact of environmental changes in deeper waters. We examined temporal changes (1998-2016) in fish diversity and community structure based on research survey data from East Greenland, over a depth gradient spanning 400 to $1500 \mathrm{~m}$. A northern and a southern continental slope region, $360 \mathrm{~km}$ apart, were analysed for temporal changes in water temperature and fish community structure. The bottom water temperature increased by up to 0.2 and $0.5^{\circ} \mathrm{C}$, respectively. Contrary to expectations, there was a concomitant loss of species richness of up to 3 and 5 species, respectively, and a decrease in total abundance in both regions. Abundances of individual species displayed different trends between regions, with 3 species of wolf fishes (Anarhichas spp.) and American plaice Hippoglossoides platessoides decreasing in the north and blue antimora Antimora rostrata, Agassiz' slickhead Alepocephalus agassizii and the roundnose grenadier Coryphaenoides rupestris decreasing in the south. The regional differences may reflect different oceanographic characteristics, as the northern region is more influenced by colder Arctic water, whereas the southern region is primarily influenced by the Subpolar Gyre (SPG). However, the observed temperature increase is expected to be due to an intensifying Atlantic Multidecadal Oscillation and/or anthropogenic climate change and not to SPG changes. The observed changes in biodiversity and community structure associated with warming are likely to affect community dynamics and alter ecosystem functioning.
\end{abstract}

KEY WORDS: Climate variability · Species richness · Deep sea $\cdot$ Demersal fish · Temporal change · North Atlantic

\section{INTRODUCTION}

As oceans temperatures rise with global warming, marine species and ecosystems are affected worldwide. The ecological effects of warming are most rapid and pronounced at high latitudes (Wassmann 2011, Fossheim et al. 2015). The Arctic seas are warming more rapidly than the global average (Hoegh-Guldberg \& Bruno 2010, Stocker et al. 2013),

${ }^{*}$ Corresponding author:

margrete.emblemsvag@moreforsking.no leading to altered habitats, poleward shifts in species distributions and changes in community organization (Mueter et al. 2009, Doney et al. 2012, Fossheim et al. 2015). Arctic fish communities react quickly to increasing temperatures due to behavioural responses that complement the demographic effects of a changing environment (Fossheim et al. 2015). The direct effects of a changing physical environment in terms of local gain or loss of fish species, and changes in

() The authors 2020. Open Access under Creative Commons by Attribution Licence. Use, distribution and reproduction are unrestricted. Authors and original publication must be credited. 
abundances, trigger higher-order effects of warming mediated by ecological interactions (Kortsch et al. 2015). The resulting impact of warming on Arctic fish is communitywide, affecting species richness, composition and relative abundances (Mueter et al. 2009, Fossheim et al. 2015). Presently, the impact of climate change on Arctic fish is primarily documented for pelagic and demersal communities living in shallower waters, but little is known about deep demersal communities, for which more marginal effects of warming have been proposed due to the greater environmental stability experienced (Yasuhara \& Danovaro 2016). A general prediction of climate change impact on high-latitude fish communities is increased species richness fuelled by poleward shifts in distribution of boreal species (Cheung et al. 2009, García Molinos et al. 2016). The expectation is supported by several recent studies showing how pelagic and demersal species rapidly expand their ranges and increase in abundance when sea ice recedes and water temperature increases (Mueter \& Litzow 2008, Fossheim et al. 2015). However, most of these studies were conducted in shallower basins or shelf areas like the Barents Sea (Fossheim et al. 2015) and the North Sea (Hiddink \& Ter Hofstede 2008, Ter Hofstede et al. 2010). Shallow marine ecosystems are exposed to daily and seasonal temperature fluctuations and are in general more influenced by changes in the atmosphere. In comparison, the deep-sea environment is considered more stable in space and time, and has therefore often been disregarded as a controlling factor of diversity (Yasuhara \& Danovaro 2016). However, several studies indicate that deep-sea bottom temperatures differ between oceans, depths and water masses and can change on both short-term (several years to decades) and long-term (centennial to millennial) time scales (Yasuhara \& Danovaro 2016). For example, in the Labrador Sea, deep-water temperatures changed at a rate of up to $\sim 0.5^{\circ} \mathrm{C}_{\text {decade }}{ }^{-1}$ over the last $60 \mathrm{yr}$ (van Aken et al. 2011).

The impact of climate warming on Arctic fish is expected to go beyond changes in species richness, and affect the local composition and abundance of species (Meredith et al. 2019). The vulnerability of a single species to climate-driven pressures, such as increasing water temperatures, is a function of its exposure, sensitivity and adaptability. Fish are adapted to a specific range of environmental conditions that the population is likely to encounter through natural variability. When the environment changes in such way that new conditions emerge and persist, the species needs to either adapt to the new environment, migrate to a new area or face local extinction
(Henson et al. 2017). Typically, mobile, short-lived species with a broad tolerance range are better able to adapt in a changing environment than more sedentary, long-lived species with restricted tolerance and habitat range (Perry et al. 2005, Danovaro et al. 2017). At high latitudes, deep demersal fish communities comprise both sedentary species narrowly adapted to local conditions, such as wolfish Anarhichas lupus, and highly mobile species with broad tolerance ranges such as Atlantic cod Gadus morhua.

The importance of both regional and local processes mediating climate-driven effects on ecological communities is illustrated in waters south and east of Greenland. As a region with adjoining cold and warm water masses, the East Greenland Ecosystem is one of the first to be affected by climatic changes (Bersch et al. 1999, Bersch 2002, Häkkinen \& Rhines 2004, Hátún et al. 2005, Bersch et al. 2007, Núñez-Riboni et al. 2013). The main circulation feature in the region is the Irminger Gyre (Våge et al. 2011), which is an integral part of the Subpolar Gyre (SPG). The SPG is a region of strong interaction between ocean and atmosphere and is thus susceptible to the effects of climate change. Natural variation in intensity and geometry of the SPG ranges from inter-annual to multi-decadal time scales, which in turn affects sea temperatures and oceanic fronts (Hátún et al. 2005). Such changes have been shown to influence faunal distribution in the eastern North Atlantic (Hátún et al. 2009a) and, more recently, the geographical distribution of redfish Sebastes mentella in the Irminger Sea (Núñez-Riboni et al. 2013). On longer time scales, the whole North Atlantic is subject to a multidecadal oscillation of sea surface temperature, i.e. the Atlantic Multidecadal Oscillation (AMO) (Kerr 2000). Moreover, sea surface temperature is rising due to climate change, and fish species are redistributing (MacKenzie et al. 2014). Cod is re-entering and spawning in the area, the abundance of mackerel Scomber scombrus is reaching levels of economic interest, and novel non-commercial species are being reported (ICES Advisory Committee 2018).

In this study, we assessed the effects of climatic variability on deep-water demersal fish communities east of Greenland by investigating temporal changes (1998-2016) in the richness, composition and community structure of species. The time series analysed pertain to an East Greenland Deep Water Survey, conducted by the Greenland Institute of Natural Resources, which covers depths ranging between 400 and $1500 \mathrm{~m}$. Based on predictions for Arctic fish communities (Cheung et al. 2009, García Molinos et al. 2016), corroborated by findings from other areas 
of the Arctic (Johannesen et al. 2012, Fossheim et al. 2015) and the Northern Atlantic (Hiddink \& Ter Hofstede 2008, Ter Hofstede et al. 2010), we expected to find an increase in species richness associated with poleward shifts of boreal species and a compositional and structural reorganization of communities.

\section{MATERIALS AND METHODS}

\subsection{Study area}

The study area covers parts of the shelf and slope area of East Greenland expanding from $61^{\circ} \mathrm{N}$ close to the southern tip of Greenland to $67^{\circ} \mathrm{N}$ west of the Denmark Strait (Fig. 1). The East Greenland Ecosystem is an area where water masses are brought together by various surface currents. On the shelf, the dominant current is the cold East Greenland Current (EGC), which flows southward carrying polar water (Våge et al. 2011) and is bordered inshore by the meltwater-driven East Greenland Coastal Current (Sutherland \& Pickart 2008). Over the deeper parts of the region, the warmer Irminger Current (IC) flows into the Irminger Sea with water temperatures of $3.5-4.0^{\circ} \mathrm{C}$ (Våge et al. 2011). The IC partly contin-

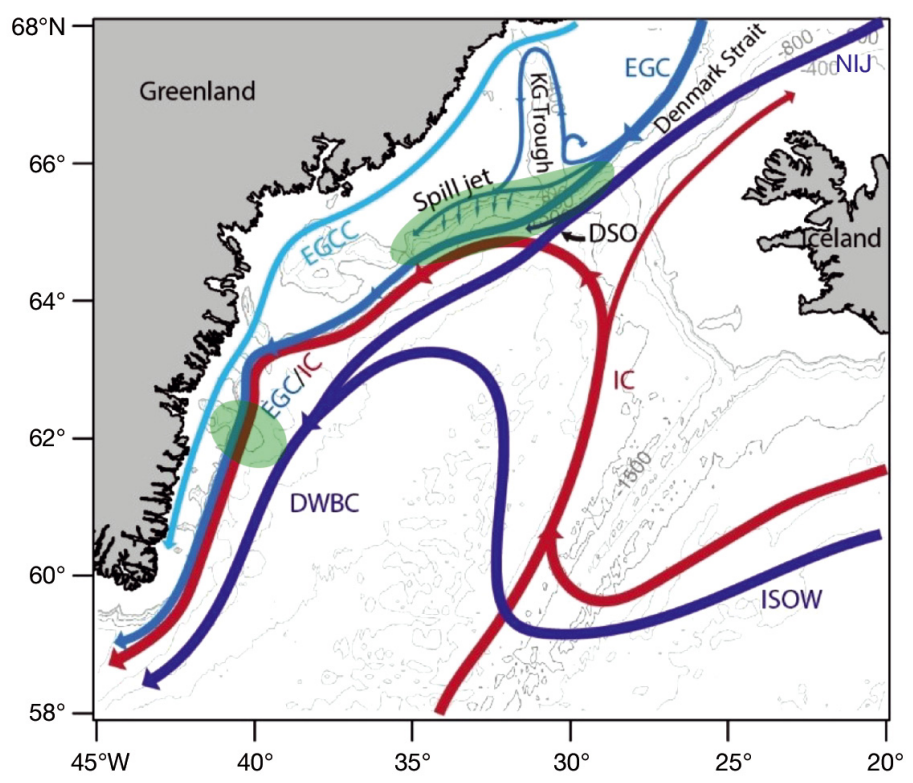

Fig. 1. Water pathways in the Irminger Sea: East Greenland Current (EGC), North Icelandic Jet (NIJ), Denmark Strait Overflow (DSO), Irminger Current (IC), Iceland Scotland Overflow Water (ISOW), Deep Western Boundary Current (DWBC), and Kangerdlugssuaq (KG) Trough. The northern and southern regions used for time series analysis are highlighted in green. ICES area 14b covers almost the entire map. Redrawn from von Appen et al. (2014) ues northward into the north Iceland Sea region, and partly turns westward to the East Greenland continental slope area. In the north, the Denmark Strait Overflow features the largest transport of dense water from the Nordic seas to the North Atlantic. The dense and cold water known as the Denmark Strait Overflow is forced through the narrow channel of the strait, runs over the sill and sinks into the deep water of the Irminger basin (Dickson \& Brown 1994).

Several countries have been fishing in the study area for decades (e.g. Germany, Greenland, Russia and Norway), primarily for Greenland halibut Reinhardtius hippoglossoides, cod and redfish. In recent years, new fisheries have been developed following shifts in fish species distribution, including new and previously unexploited species entering the ecosystem, like mackerel (Jansen et al. 2016).

\subsection{Sampling design}

We used data from the annual Greenland DeepWater Survey carried out since 1998 by the Greenland Institute of Natural Resources. The survey covers the International Council for the Exploration of the Sea (ICES) area $14 \mathrm{~b}$, between $60^{\circ}$ and $67^{\circ} \mathrm{N}$ and between the 3 nautical mile (n mile) line and the $200 \mathrm{n}$ mile line (midline to Iceland), at depths ranging from 400 to $1500 \mathrm{~m}$. The survey follows a bottomtrawl, buffered, stratified random design (Kingsley et al. 2004). Throughout the time series, an Alfredo III trawl with a mesh size of $140 \mathrm{~mm}$, and a $30 \mathrm{~mm}$ mesh liner in the cod-end, was used. The ground gear was of the rock hopper type. Towing time was usually $30 \mathrm{~min}$, but towing times down to $15 \mathrm{~min}$ were accepted. Average towing speed was 3.0 knots. After each haul, the catch was sorted and species were counted and weighed to the nearest $0.1 \mathrm{~kg}$. The species determination on the survey is conducted by trained personnel and supported by species experts in case of doubt. Thus the survey was considered consistent throughout the time series. Until 2008, the survey was conducted in June/July, a period when ice cover could challenge sampling. From 2008 onward, to avoid the problems related to ice cover, the survey was postponed to August/September. Also, in 2008 the survey was combined with a new shrimp/ fish survey, which led to a change in trawling hours so that most of the stations were sampled during the night. Prior to the change in timing of the survey, a comparative analysis was performed on commercial catch rates which showed only minor effects of changing the sampling period (Christensen \& Hede- 
holm 2016). The change in sampling time is therefore not likely to have affected the results. In the present study, we used yearly data from 1998 to 2016, with the exception of 2001, when no survey was conducted. A total of 1060 stations, ranging from 40 to 100 per year, were included in this study.

Prior to the analyses, the data were screened, quality checked and pre-processed. Only fish classified to species level were retained. Several species were classified as pelagic (Haedrich \& Merrett 1988, Froese \& Pauly 2017) and were likely caught during setting and hauling of the trawl; these pelagic species were removed from the dataset. As the dataset consisted of a large number of rare species, only species present in more than $1 \%$ of the samples were included in the analyses, resulting in a final dataset of 61 species. Prior to analysis, catches were standardized to numbers per unit area based on the area swept by each haul (numbers $\mathrm{km}^{-2}$ ). Before analysis on abundance, data were log transformed using natural log base.

As a measure of fishing effect in the area, fishing effort given as hours of fishing was calculated for the commercial species of ICES area 14b. Calculations are based on haul duration in logbook data obtained from the Greenland Fishery and Hunting License office.

\subsection{Environmental drivers}

Near-bottom temperatures were measured in $0.1^{\circ} \mathrm{C}$ increments, with a Seamon sensor mounted on the trawl door. In the following, these observations will be referred to as 'trawl temperature observations' (TTOs). To construct climate temperature indices, the TTOs were additionally supported by all available historical temperature observations from conductivity-temperature-depth (CTD) profiles in the study area. A total of 161000 CTD profiles from the World Ocean Database, ICES, Coriolis and some proprietary data of the Thünen Institute for Sea Fisheries were gathered. Finally, sea surface height (SSH) data from satellite altimetry were provided by Archiving, Validation and Interpretation of Satellite Oceanographic Data (AVISO).

\subsection{Data analysis}

\subsubsection{Oceanographic parameters}

In situ hydrography data were gridded with the physical-statistical model Adjusted Hydrography Op- timal Interpolation (AHOI; Núñez-Riboni \& Akimova 2015). AHOI has been validated by comparing its salinity variations with independent variations of its driving mechanisms in the North Sea (Núñez-Riboni \& Akimova 2017). Additionally, for the particular case of the Irminger Sea, temperature output from AHOI has been compared with variations of the current intensity as characterized by the SPG index (Hátún et al. 2005). A drawback of AHOI are regional biases arising from the calculation of the average fields of the Gauss-Markov interpolation (Núñez-Riboni \& Akimova 2015). The TTOs can be strongly influenced by sampling location and depth, as well as by important short-term temperature variations at daily and monthly scales, like eddies, tides and current meanders. Thus, the TTOs alone are not suitable for estimating multi-decadal climatic trends. To deal with this, TTOs and AHOI maps were combined as follows: temperature maps were interpolated over central positions on the continental shelf, at each depth stratum, obtaining standardized temperature climate indices. To remove the spatial bias from the long-term average, an off-set was added to (or subtracted from) these AHOI indices based on the time average of the TTOs at each depth stratum. These climate indices were calculated with temperature from the third year quarter (July, August, September).

An SPG index was calculated as the first principal component from SSH altimetry from AVISO data in the region $70^{\circ}-15^{\circ} \mathrm{W}$ and $47^{\circ}-68^{\circ} \mathrm{N}$. This index is similar to the SPG index of Hátún et al. (2005), reflecting the current intensity and temperature in the central SPG. The index is sometimes obtained with the second principal component, depending on the altimetry data source and chosen spatial domain (Hátún \& Chafik 2018).

An index for the AMO (basically the average sea surface temperature of the North Atlantic) was downloaded from the internet portal of the Climate Time Series at the Earth System Research Laboratory of the National Oceanic and Atmospheric Administration (NOAA 2018).

\subsubsection{Community structure}

Multivariate analyses were used to describe the spatial organization of fish communities and investigate temporal trends in community structure. Distinct fish assemblages were identified by hierarchical clustering of species abundance data, using Bray Curtis similarity and Ward linkage. Visual inspection of the resulting dendrogram (Fig. S1 in the Supple- 
ment at www.int-res.com/articles/suppl/m654p127 supp.pdf), and related non-metric multidimensional scaling (nMDS) map (Fig. S2), indicated 6 clusters of distinct fish assemblages that were spatially separated (Fig. S3), due to differences in their depth, TTOs and latitudinal distributions (Fig. S4).

Relative abundance across all assemblages and indicator values of single species within each assemblage were calculated (Figs. S5-S7, Table S1). Indicator species were identified based on the method of Dufréne \& Legendre (1997) using the 'labdsv' package in R. This method calculates the probability of obtaining as high an indicator value (fidelity and relative abundance) as observed over specified iterations. Species response curves were calculated for indicator species within each assemblage along gradients of depth and TTOs (Fig. S8). To test for differences between assemblages in depth, TTOs and latitude, an F-test was used followed by a Tukey HSD post hoc test (Table S2).

\subsubsection{Temporal changes in bottom temperature, species richness and total abundance}

For trend analyses of AHOI bottom temperature, species richness and total abundance, only samples from the 2 continental slope areas were included. These areas were sampled consistently and had a similar depth range, allowing a direct comparison of these 2 distinct regions (Fig. 2). In addition, results from the analysis of community structure showed that sites located on the shelf (especially sites located furthest to the north) differ from the other study sites regarding species composition and habitat. The shelf stations were therefore excluded to avoid bias. The 2 slope areas, referred to as northern and southern regions, were analysed separately and compared.

To test for differences in trends over the depth range, 3 depth intervals were specified (400-800, 800-1000 and 1000-1500 m), to balance sampling and obtain a sufficient number of stations per year and depth interval. The AHOI bottom temperature, species richness and total species abundance were modelled as a function of time using generalized linear models (GLMs) (McCullagh \& Nelder 1989). An interaction term between time (year) and strata was included to test for differences in trends across depth intervals. Models of species richness and abundance included the covariates longitude and latitude to correct for spatial bias. Statistical modelling parameters are summarized in Tables S3-S5.

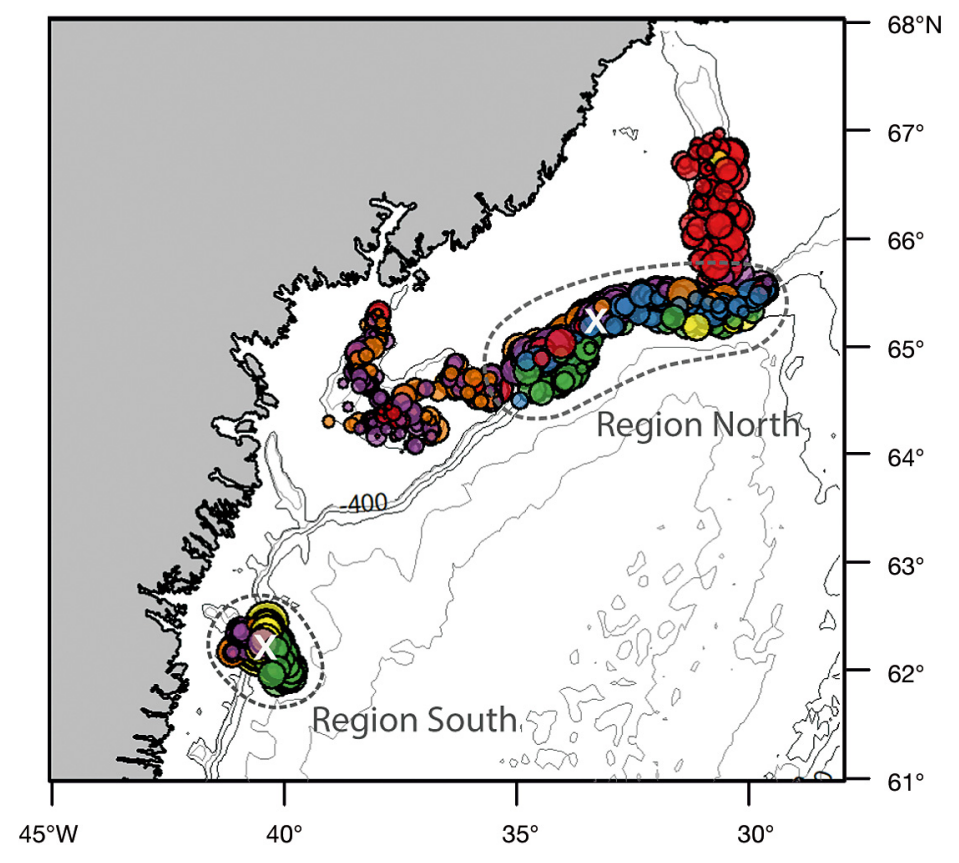

Fig. 2. Study area with sampling sites. Sites are colour-coded according to Assemblages 1 to 6 (red, blue, green, purple, orange and yellow, respectively, as described in Section 3.2). Sizes of points are proportional to species richness at the site. Dashed ellipses mark the northern and southern slope regions used for analysis of temporal change in community structure. The white markings $(\mathrm{X})$ represent the positions where climate indices were calculated for the 2 regions (see Section 2.4.1)

A redundancy analysis (RDA) (Legendre \& Legendre 2012) was used to model and summarize changes in abundance of single species in relation with time, TTOs and depth. For the northern region, which covers a larger area along the shelf, latitude was also included in the RDA.

All statistical analyses were done with the software $\mathrm{R}$ version 3.3.1 (R Development Core Team 2016). Analyses of fish community data were performed with the package 'vegan' (Oksanen et al. 2017). Indicator species were identified using the package 'labdsv' (Roberts 2016), and species response curves were obtained using the package 'mgcv' (Wood 2017).

\section{RESULTS}

\subsection{Oceanographic parameters}

The SPG was in a positive phase at the beginning of the study period, indicating strong currents and low temperatures in the central SPG (Fig. S9), then decreased to a minimum in 1998, indicating weak currents and higher temperatures. Subsequently, the 
SPG index oscillated inter-annually until 2010, when it again entered a positive phase similar to the one at the beginning of the study period. The AMO gradually increased through the study period, indicating an increase in temperature (Fig. S9).

\subsection{Community structure}

A total of 103 demersal fish species were caught during the $18 \mathrm{yr}$ time series; of these, 61 fish species (59\% of total) were used in the analysis (species list in Table S1). The clustering resulted in 6 well defined and distinct assemblages (Fig. 2, Figs. S1 \& S2), and was mainly driven by differences in abundance between sites and not by the replacement of species (Figs. S5-S7). The different assemblages were associated with different depths, latitudes and temperatures (Table S2). Assemblage 1 (red sites) was separated from the 2 other shelf assemblages ( 4 and 5) mainly by temperature, which is significantly lower in this area. The main indicator species of this assemblage was polar cod Boreogadus saida. Assemblage 2 (blue sites) was located at the edge of the slope and was the shallowest of the slope assemblages. The main indicator species was roughhead grenadier Macrourus berglax. Assemblage 3 (green sites) was the deepest assemblage whose main indicator species was the deep-water species Agassiz' slickhead Alepocephalus agassizii. Assemblage 4 (purple sites) was found at warmer and shallow sites on the continental shelf and along the ridge, with the indicator species greater argentine Argentina silus. Assemblage 5 (orange sites) was found at the shallowest sites on the shelf and along the ridge of the slope. The indicator species here was the golden redfish Sebastes marinus. Assemblage 6 (yellow sites) was located in the middle of the slope and was characterized by the indicator species roundnose grenadier Coryphaenoides rupestris. A more detailed description of the depth range, temperature range and listing of indicator species for each assemblage is provided Text $\mathrm{S} 1$.

\subsection{Temporal changes in bottom temperature, species richness and total species abundance}

\subsubsection{Bottom temperature}

The AHOI bottom temperature increased in all strata in both regions (Fig. 3). As expected, the deepest strata were the coldest, and the shallowest were the warmest. Regional differences were pres- ent, with temperatures being generally lower in the northern region by approximately $1^{\circ} \mathrm{C}$ in all strata.

Over the study period, AHOI bottom temperatures of the northern region increased by $0.14,0.18$ and $0.23^{\circ} \mathrm{C}$ in the shallow, middle and deep stratum, respectively. In the southern region, the increase was generally larger, with increases of $0.38,0.40$ and $0.45^{\circ} \mathrm{C}$ in the shallow, middle and deep stratum, respectively (Table $\mathrm{S} 3$ ).

Within the study area, the fastest increase in temperature occurred along the continental slope, with changes of up to approximately $0.5^{\circ} \mathrm{C}$ in the southern region, whereas the shelf area $(<400 \mathrm{~m})$ experienced a slight cooling (Fig. 4).

\subsubsection{Species richness}

The 2 regions differed with regard to species richness (Fig. 3). Although the difference was not significant, the southern region was slightly more diverse $(10.3 \pm 0.2 \mathrm{SE})$ than the northern region $(9.4 \pm$ $0.13 \mathrm{SE}$ ). In the northern region, species richness was highest in the shallow stratum, whereas in the southern region, the middle stratum was the most diverse and the shallow stratum was the least diverse.

In the northern region, the slope of the temporal trend in species richness was contingent on depth, with a significant interaction term between year and depth stratum in the model $(\mathrm{p}<0.05)$. The shallow and middle stratum experienced a local loss of diversity of 2.6 and 3.1 species, respectively, whereas the deep stratum was stable through time. Species richness in the southern region was generally higher than in the northern region, but decreased more rapidly through time, although not significantly. Species richness decreased in the shallow stratum, mid stratum and deep stratum by 2.4, 4.3 and 1.5 species, respectively. Differences in slopes between strata were not statistically significant (Fig. 3, Table S4).

\subsubsection{Total abundance}

Total species abundance was higher in the southern region, where it also decreased at a higher rate (Fig. 3). In this region, total species abundance decreased through time in all strata, but the rate of change was higher in the middle stratum $(\mathrm{p}<0.05$, Table S5). In the northern region, species abundance also decreased through time in all strata, but did so at a higher rate in the shallow stratum $(\mathrm{p}<0.05$, Table S5). 

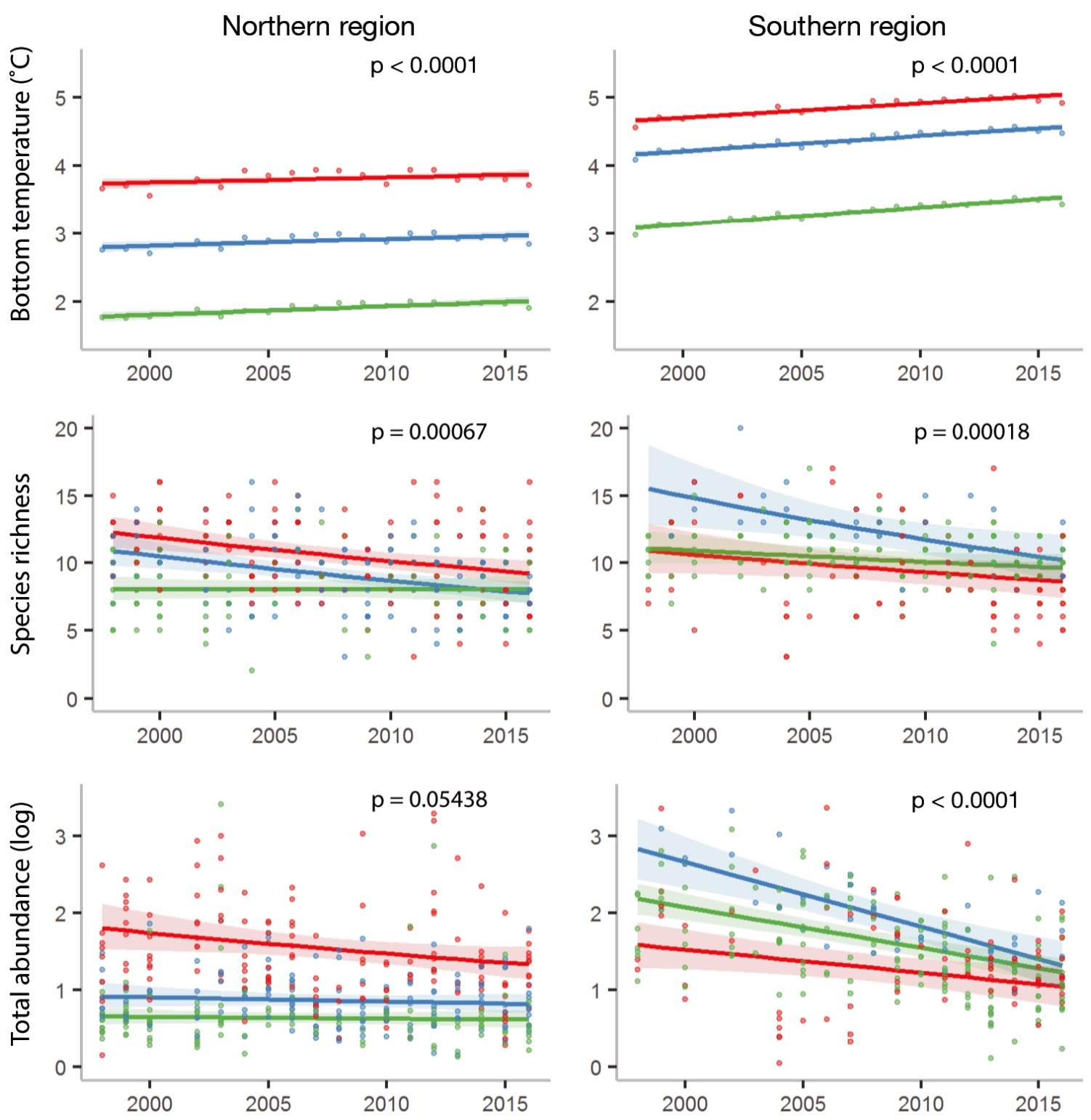

Fig. 3. Temporal trends in Adjusted Hydrography Optimal Interpolation (AHOI) bottom temperature (top panels), species richness (middle panels) and total species abundance (bottom panels) for the northern (left panels) and southern (right panels) regions. Trend lines were obtained by GLM (predicted marginal effects of model terms) and points show raw data (red: shallow strata; blue: middle strata; green: deep strata). Shaded area around trend lines represents confidence intervals, and p-values refer to temporal trends. Only stations from the 2 slope regions indicated in Figs. $1 \& 2$ were included in these analyses

\subsubsection{Individual species abundances}

The individual species abundances showed different trends and inter-annual fluctuations through the study period (see Figs. 5 \& 6). The RDA ordination summarizes how abundance increased or decreased over time for the different species (Figs. S10 \& S11). Species displaying the most rapid changes in abundance differed between the 2 regions.

In the northern region, the species decreasing most rapidly were the Greenland halibut Rein- hardtius hippoglossoides, 3 species of wolffish (Anarhichas minor, A. denticulatus and A. lupus), American plaice Hippoglossoides platessoides and Kaup's arrowtooth eel Synaphobranchus kaupii (Fig. 5). In the southern region, the species decreasing most rapidly in abundance were Greenland halibut, blue antimora Antimora rostrata, Agassiz' slickhead, Günther's grenadier Coryphaenoides guentheri, roundnose grenadier and Murray's longsnout grenadier Trachyrhynchus murrayi (Fig. 6). 


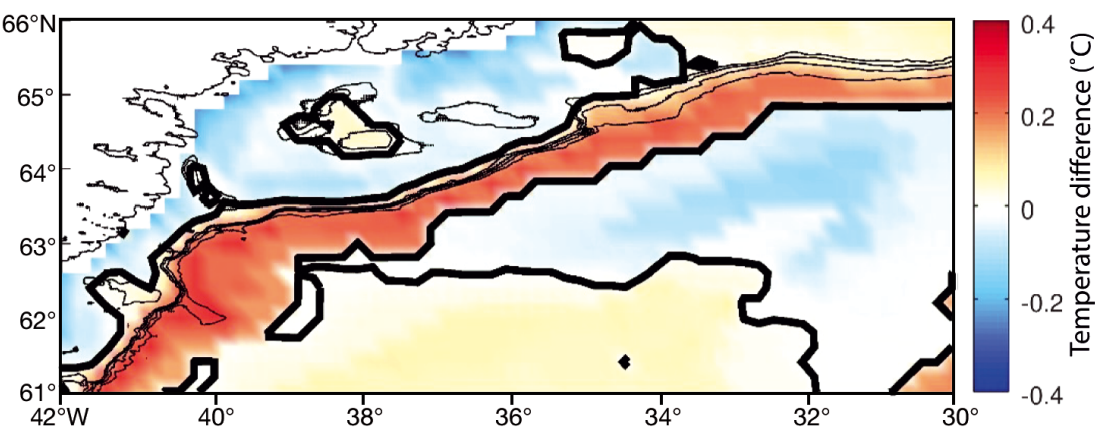

Fig. 4. Adjusted Hydrography Optimal Interpolation (AHOI) bottom temperature differences between 2 averaged periods (2007-2015 minus 1998-2006).

Black thick lines indicate regions of no change

Besides tusk Brosme brosme and the greater argentine, species increasing in abundance also differed between regions. In the northern region, the main species were roughhead grenadier Macrourus berglax, snubnosed spiny eel Notacanthus chemnitzii and blue ling Molva dipterygius. In the southern region, the main species were lancet fish Notoscopelus kroeyeri, smallmouth spiny eel Polyacanthonotus rissoanus and northern wolfish $A$. denticulatus (Figs. $5 \& 6$ ).

\subsubsection{Fishing effort}

During the study period, there was a decline in fishing effort of the main commercial species Greenland halibut and redfish after 2004, whereas the effort of catching cod started to increase after 2010 with a small peak in 2015. There were no fisheries targeting the two pelagic species Atlantic herring Clupea harengus and Atlantic mackerel Scombrus scombrus until 2010 when the fishery started and the effort increased. Fishing effort of the northern shrimp Pandalus borealis declined rapidly after 2004 and reached zero by 2016 (Fig. S12).

\section{DISCUSSION}

We found local decreases in species richness and total abundance in East Greenland deep-water demersal fish communities, concomitant with a rise in

\section{Northern region}
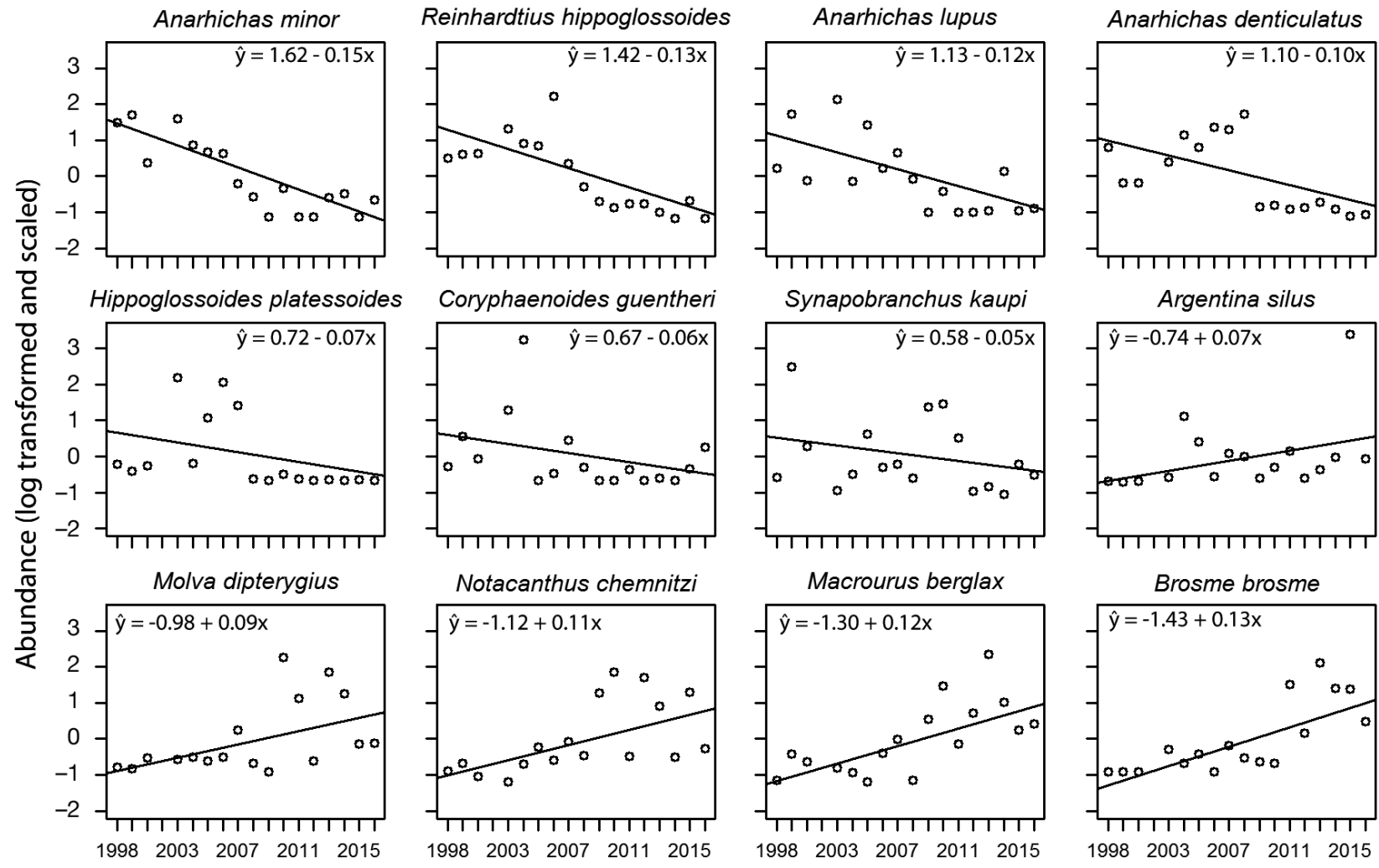

Synapobranchus kaupi

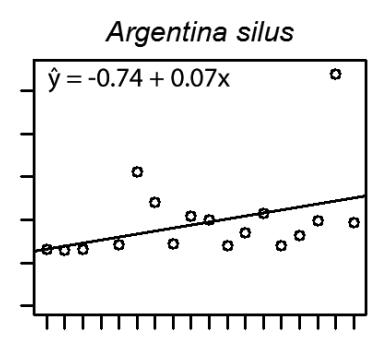

Notacanthus chemnitzi
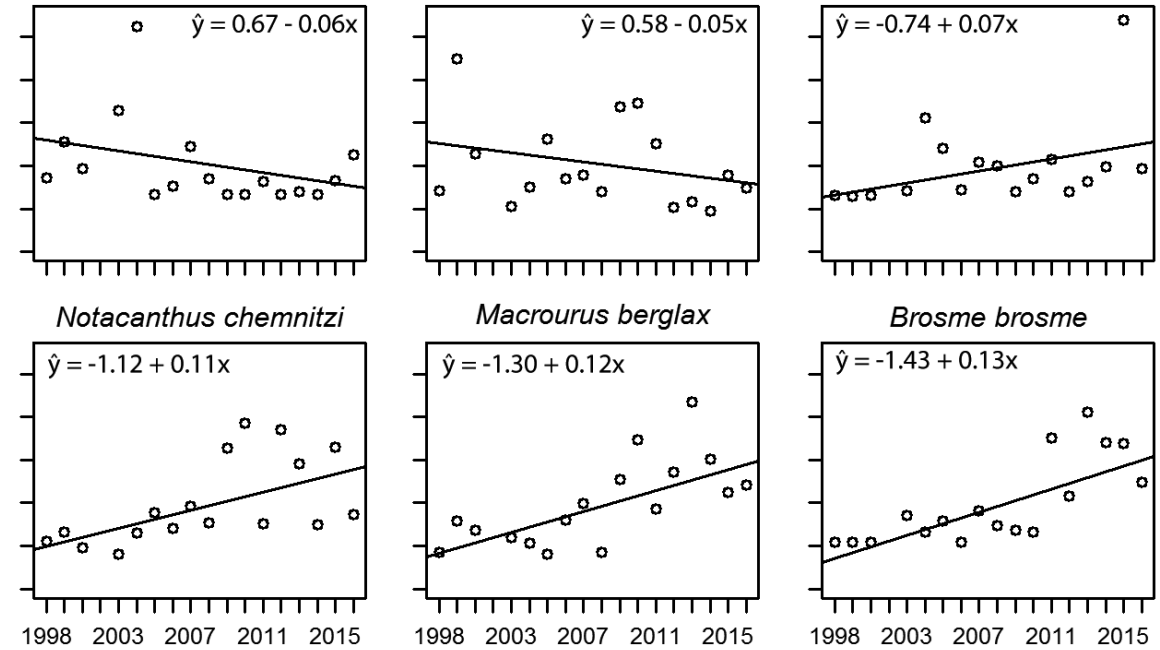

Fig. 5. Species displaying most rapid increase or decrease in abundance (log transformed and scaled) in the northern region 


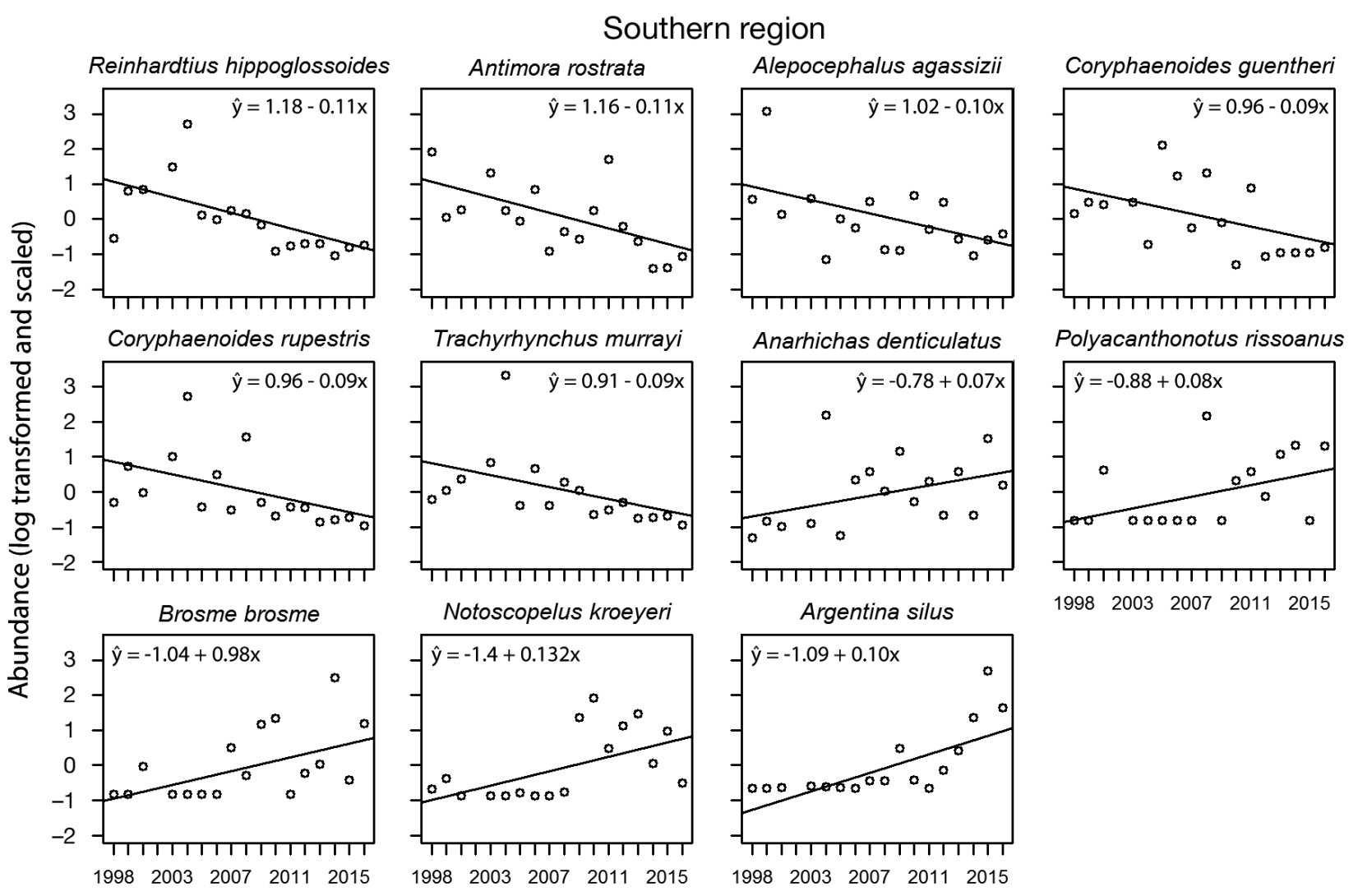

Fig. 6. Species displaying most rapid increase or decrease in abundance (log transformed and scaled) in the southern region

AHOI bottom temperatures, during a period (19982016) characterized by rapid warming of polar regions (Meredith et al. 2019). The trends were significant in both investigated slope areas, despite their oceanographic differences. The rates of change varied with depth, which, together with water temperature, was the main structuring environmental gradient for these fish assemblages. Abundances of individual species displayed different trends between investigated areas, with 3 species of wolffish, American plaice and Kaup's arrowtooth eel decreasing in the north, and blue antimora, Agassiz' slickhead and Günther's grenadier decreasing in the south. The regional differences may reflect different oceanographic characteristics, as the northern region is more influenced by colder Arctic water, whereas the southern region is primarily influenced by the SPG. Our results indicate extensive ecological change in the deep sea, likely influenced by the direct effect of temperature rise and indirect effects mediated by changes in habitat and species interactions. The observed changes in the deep-sea fish communities happened rapidly, emphasizing the urgent need for ecosystem-based approaches and climate adaptation in fisheries management.

\subsection{Impact of climate and oceanography on diversity}

The general prediction of macro-ecological trends of fish diversity in response to rising temperatures in subpolar regions is an increase in species richness due to poleward shifts of temperate species (Cheung et al. 2009). Our findings, on the other hand, showed an overall decline in species richness as water temperatures increased. The oceanographic characteristics of East Greenland help explain the decline in richness in the context of climate warming. Ecological responses have been linked to oceanographic interannual variability associated with the SPG (Hátún et al. 2005, Núñez-Riboni et al. 2013, Hátún \& Chafik 2018), whereas multi-decadal variability is affected by the AMO (Kerr 2000, Nye et al. 2009, Alheit et al. 2014). In addition to these sources of variability, climate change drives long-term changes. Interannual fluctuations of the SPG cause shifts in temperatures and fronts, which ultimately affect population distributions and densities either directly or indirectly via e.g. changes in favourable spawning grounds and nursing areas, shifts in lower trophic levels, prey availability, predator abundances and 
year class success (Hátún et al. 2009a,b, NúñezRiboni et al. 2013). In southeast Greenland, the SPG is correlated to redfish distribution (Pedchenko 2005, Núñez-Riboni et al. 2013) and is likely to influence the distribution of other species, possibly affecting the overall trend in species richness and abundance. However, the overall temperature trend through the study period does not correspond to changes in the SPG, which changed from a positive into a negative phase in 1996, and became positive again at the end of the study period. The steadily increasing temperatures along the continental shelf rather suggest warming of the IC due to reasons other than the SPG. The most probable cause seems to be an increase of temperature upstream along the IC, possibly caused by the AMO and/or by anthropogenic climate change. The long-term negative trend in richness is a likely response to the long-term, climate-driven oceanographic changes through environmental filtering of Arctic species and physical and topographic constraints on distributional shifts of boreal species, discussed further below.

In a nearby study area southwest of Iceland, covering similar depths, species richness is increasing as expected (Stefansdottir et al. 2010). The area is influenced by the warm-water IC, which is a likely conveyor of temperate fish species moving northward to both Iceland and our study region. A small branch of the IC splits to the north, west of Iceland, along the shelf, through the Denmark Strait. This branch of temperate water, in addition to local upwelling and high productivity, helps to explain the observed increase in species richness southwest of Iceland. Along East Greenland, however, the warm IC mixes with the Arctic EGC, which makes the study regions in East Greenland hydrographically different from the area southwest of Iceland. Fock (2008) investigated driving forces of groundfish assemblages on the shelf area $(0-400 \mathrm{~m})$ of West Greenland and East Greenland between 1981 and 2006 and found climate (using Nuuk annual air temperature as proxy for climate change) to be a stronger driver of community dynamics (community interactions and environmental relationship) in East Greenland compared to West Greenland. This might indicate that the East Greenland ecosystem is more vulnerable to climate change. Considering the rapid observed temporal changes in the deep ocean over the last 2 decades, one would expect temporal changes in fish communities also in the shallower shelf area. Regional differences based on topography and oceanographic conditions such as depth, different water masses, currents and fronts are important considerations in how fish communities respond to cli- mate variability (Pinsky et al. 2013). Looking at large areas as a whole, one can easily overlook regional and local differences that are important in understanding responses in the ecosystem.

The depth- and area-specific responses in water temperature were accompanied by differences in trends of species richness, varying from no change to a rapid decline. The different local trends in species richness highlight the importance of local oceanographic and ecological conditions in mediating climate effects. The study regions experience southward currents, the IC and EGC, along which temperate and cold-water species may disperse, respectively. The climate-driven changes in hydrographic characteristics may affect fish communities in our study regions either directly, through environmental filtering where the environment selects against certain species, or indirectly, via changes in resource productivity and altered species interactions.

\subsection{Temporal change in community structure}

Although the northern and southern study regions covered the same depth ranges, the community dynamics differed. In marine environments, assemblage structure and diversity are strongly correlated with depth, but patterns of faunal change vary considerably from area to area (Gage \& Tyler 1991). In our study, this was highlighted by different trends in species richness and total abundance between depth strata and between regions. The difference between regions might be associated with a more rapid temperature increase along the slope of the southern region. The latter could be explained by the stronger influence of the IC and the greater distance from the Denmark Strait and the cold-water flow from the north. The northern region is located where the IC and the EGC meet and thus the mixing of the two water masses might be less pronounced with a smaller influence of the warmer IC. Although there are several controlling factors of diversity such as harvesting (Smith et al. 2000, Worm et al. 2009, Nogueira et al. 2016), productivity, habitat characteristics and species interactions (Levin et al. 2001), water temperature is a strong candidate (Fossheim et al. 2015).

In the deep demersal communities, species richness may decline with warming due to characteristics of deep-water species. In contrast to shallowwater and pelagic species, poleward shifts of deep demersal species are expected to happen at a slower pace due to their relatively low mobility and slow life histories. Further, being more stationary, deep dem- 
ersal species are more vulnerable to environmental filtering. As temperatures of the IC increase, conditions are worsening for the cold-water species, and may negatively affect their vital rates. In support of this hypothesis, we found that some of the 'slow' species, such as Greenland halibut and wolffishes, and species categorized as Arctic or arcto-boreal (Mecklenburg et al. 2018), were generally becoming less abundant. However, more research is needed to determine whether changes in community dynamics are demographically or behaviourally (migration) driven, or a combination of both.

We also saw an increase of certain species. Common for both regions are tusk and the greater argentine, which are both boreal species. These are also reported to be rapidly increasing in shallower depths on the shelf area (Post et al. 2020). Tusk, which was initially absent, displayed substantial increases in abundances in both regions. Previously, tusk was found at the southern tip of Greenland, with only stray appearances in East Greenland (Cohen et al. 1990). Elsewhere, in the Gulf of Maine, a distributional shift of tusk is projected as a result of spatial mismatch between suitable habitat and temperature (Hare et al. 2012). The increased abundance of tusk in East Greenland might therefore be driven by environmental change and redistribution. The greater argentine is a bathydemersal/-pelagic species with relatively high temperature preferences (Cohen et al. 1990). Although this is a schooling fish with patchy appearances, the increase of this species might be a result of rise in water temperatures and more favourable habitats. On the other hand, the greater argentine is a common bycatch in both the Greenland halibut and the redfish fishery (ICES Advisory Committee 2018), and the observed increase in abundance could also partly be a result of decreasing fishing effort, combined with the adoption of sorting grills by the shrimp fishery in 2002. The main species that are increasing in both regions are all categorized as boreal species, except northern wolffish, which is categorized as boreal-Arctic (Mecklenburg et al. 2018). This indicates that the so called 'borealization' of the demersal fish communities seen elsewhere in high-altitude regions (Fossheim et al. 2015) might also be happening in deeper waters of East Greenland.

The East Greenland deep water survey changed the sampling design in 2008 where time of the survey was shifted from June/July to August/September due to sea ice challenges. It is unlikely that this shift has affected the results. A sampling shift of $1 \mathrm{mo}$ within the same season at these depths should not cause the magnitude of change that we observed.
Further, the expected effect of a one-time shift in the timing of sampling would be a more abrupt change in 2008 rather than the gradual change over several years, observed in this study.

\subsection{Distributional shifts}

Demersal species are less mobile than pelagic species and are likely to migrate in the direction of currents following the ocean floor within their depth range. The northward migration of temperate species originating further south probably follows the path of the warm IC reaching the south of Iceland first, before further migration westward to East Greenland. These species would reach the northern region first and then disperse southwards following the mixed IC and EGC along the continental shelf. Importance of current properties and directions in creating a pathway for transport of species is also seen in other high-latitude systems such as the Barents Sea, where the warm north-running Gulf Stream supplies Atlantic species to the western Barents Sea, resulting in higher species richness than in the east (Johannesen et al. 2012).

New recordings of species in East Greenland that may have arrived due to temperature rise are mainly from waters with depth less than $400 \mathrm{~m}$ (Møller et al. 2010). In the present dataset, there are recordings of species in the later survey years that are absent in the early years. For example, the temperate species sea lamprey Petromyzon marinus was caught during the survey in 2013 in the southern region and in 2008 and between 2011 and 2014 in the northern region. The sea lamprey is described to occur south of Greenland and in sporadic occurrences with increasing frequency off Iceland (Astthorsson \& Palsson 2006). This species has also been recorded as 'new' in Icelandic waters, where specimens have been assigned to the European stock, which supports the theory of large-scale migrations (Pereira et al. 2012).

Even though 'new' species are being recorded east of Greenland, species richness is declining. A possible explanation might be that the colder water off East Greenland inhibits the migration of some of the temperate species further from the Icelandic shelf into the Greenlandic waters where the temperate IC meets the cold EGC. The southward direction of flowing water masses and the shallow and narrow topography of the Denmark Strait might act, respectively, as an environmental and physical barrier for deep demersal species trying to reach colder waters further north. In support of this hypothesis, the shallow strait is suggested as a cause for the distinction of 2 populations of 
Greenland halibut in the Atlantic (Albert \& Vollen 2015, Westgaard et al. 2017). Topographic constraints are also reported as the reason for limited migration off the isolated Flemish Cap, an international fishing ground off Newfoundland, where shallow demersal species such as Atlantic cod are inhibited by the deep waters surrounding it (Konstantinov 1970). If northward migration is inhibited, species might shift depth distributions to reach colder waters. This is seen in the gulf of Mexico, where the topographic constraints of the coastline are causing assemblages to go deeper (Pinsky et al. 2013). Distributional shifts are most likely happening along the slope in East Greenland, depending on species location, preferences and available habitat. Due to regional and local differences in climate velocities, the large depth range and the complex oceanography of this area, species responses are likely heterogeneous, making it difficult to find specific patterns at assemblage levels or linking the assemblage changes to species characteristics or traits.

An $18 \mathrm{yr}$ time series is relatively short to effectively isolate a climate signal from the multi-decadal variability. However, during this period, there was a significant increase in water temperature and a decrease in species richness. If, as we propose, this observed loss of species was related to the temperature increase and to limited possibilities of range shifts due to barriers like current directions and the Denmark Strait, East Greenland might be a so-called 'dead end' for deep-water demersal species. Such regions in the oceans, with barriers, are projected to limit range shifts under climate change, resulting in larger relative decreases in species richness (Cheung et al. 2013, Burrows et al. 2014, Jones \& Cheung 2015, Rutterford et al. 2015). Identifying whether the East Greenland region represents such a barrier is of great importance for prediction and management decisions. A study on geographical redistribution of species in an extended study area is needed to determine whether this is the case.

\subsection{Top down effect of a new predator and fishery}

The abundance of Atlantic cod has rapidly increased in the last decade. Top predators such as cod can have a strong impact on prey abundances and behaviour (Pauly et al. 2005, Rochet et al. 2013). At the Flemish Cap, species diversity dropped when cod started to recover from the collapse in 1998 (Nogueira et al. 2016). Although the abundance of cod in the depth ranges of this study were relatively low, cod were present and increasing in abundance at depths from 400-700 m, especially in the northern region. In shallower waters above $400 \mathrm{~m}$ on the shelf area, cod, along with redfish, is highly dominant in the fish community. Recent analyses of cod stomach contents in the East Greenland area reveals a diet of crustaceans, krill and small fish likely to be mesopelagic species (Hedeholm et al. 2017). Although stomach analysis does not reveal predation on the species analysed in the present study, the presence of cod could cause avoidance behaviour in potential prey species, shifts in distribution (ICES Advisory Committee 2018) and change of habitat (Worm \& Myers 2003, Frank et al. 2007). Cod predation has been described as the main source of small redfish mortality (Lilly 1987, Pérez-Rodríguez \& Saborido-Rey 2012). Fock (2008) found fishing mortality of cod to be positively correlated to abundance of redfish juveniles in East Greenland, indicating the influence of cod as predator. Predation also depends on the densities of prey species as shown on the Flemish Cap, where small redfish are prey of cod in years with successful redfish recruitment events (NAFO 2015, Nogueira et al. 2018). The great cod collapse of the 1990s had a major impact on ecosystems elsewhere (Pace et al. 1999, Choi et al. 2004, Nogueira et al. 2018), but insufficient survey data exist prior to the cod collapse in Greenland, so it is not known how the disappearance of cod impacted trophic levels, or how the system will respond as the cod stock rebuilds. The relatively low abundance of cod in the southern region, where species richness decreased the most, suggests that the return of cod may not be a main driver of the observed diversity loss. However, if the northern region serves as a general source population for the southern region, the increase in cod could have affected diversity in East Greenland. To our knowledge, there are presently no studies or data in support of this hypothesis. More research on food webs and community dynamics is needed to determine how the presence of top predators may affect diversity and ecosystem structure.

East Greenland is an international fishing ground, and it is therefore plausible to assume that the fishery is affecting diversity. Fisheries can cause major disruptions to an ecosystem by affecting the energy flow in the natural food web and causing declines in fish population abundance. In East Greenland, fisheries have been present throughout the study period, but there has been a decrease in commercial fishing effort (Greenland halibut, northern shrimp and redfish), which indicates that fisheries are not the main driver of the observed changes. Bycatch of species may have provoked changes in community dynamics, especially 
until 2002, when mandatory sorting grids where introduced in the shrimp fishery. This measure reduced the bycatch of species considerably, and the fishery in East Greenland is now considered to be clean (ICES Advisory Committee 2018). Based on comparison of fishing effort and results of this study, a conclusive effect of the fishery on overall decreased species richness and abundance is not likely. However, additional effects of the fishery and possible interactions between climate and fishing on ecosystem sensitivity, cannot be disregarded (Perry et al. 2005). If species richness continues to decline, the ecosystem might become less resilient to fisheries as cold and speciespoor communities are likely top-down controlled (Frank et al. 2007). Based on this assumption, removing predators might have a larger impact on the East Greenland ecosystem than expected and should therefore be considered in management.

\section{CONCLUSION}

We show that deep-water fish communities respond to long-term changes in climate and hydrographic conditions. Species richness and total abundance rapidly decreased concomitantly with an increase in bottom temperature. These observations contradict the general expectation of a delayed response to warming in deep-sea communities and an expected increase in diversity and abundance at high latitudes due to northward migration of temperate species. The results highlight the importance of regional and local oceanographic and topographic conditions in understanding how fish communities respond to a changing environment.

In East Greenland, warming of the IC upstream, due to an increasing phase of the AMO and/or possibly anthropogenic climate change, is a likely driver of the observed trends in deep-water demersal fish. Possible explanations for the loss of species richness and the decrease in abundance are that deep coldwater species might be struggling to follow climate velocities due to slow behavioural responses, and/or that regional topography and oceanography create a geographical and physical barrier for northward shifts. If the observed ecological trend continues in the future, as seems likely considering climate change projections, the overall vulnerability of the ecosystem will increase accordingly. Maintaining high taxonomic and functional diversity is important in buffering against climate variability, climate change and overexploitation, thereby reducing the risk of collapse of fish stocks and ecosystems.
Acknowledgements. This study was supported by the CLIMA project, reference RER 15/0008, funded by the Ministry of Foreign Affairs in Norway. We thank the data collectors of the annual Greenland Deep-Water Survey, and the participants of the CLIMA project for valuable discussions and input. We also thank 3 anonymous reviewers and the Contributing Editor Prof. Franz J. Mueter, whose comments and suggestions greatly helped improve this manuscript.

\section{LITERATURE CITED}

Albert OT, Vollen T (2015) A major nursery area around the Svalbard archipelago provides recruits for the stocks in both Greenland halibut management areas in the Northeast Atlantic. ICES J Mar Sci 72:872-879

Alheit J, Licandro P, Coombs S, Garcia A and others (2014) Reprint of 'Atlantic Multidecadal Oscillation (AMO) modulates dynamics of small pelagic fishes and ecosystem regime shifts in the eastern North and Central Atlantic'. J Mar Syst 133:88-102

Astthorsson O, Palsson J (2006) New fish records and records of rare southern species in Icelandic waters in the warm period 1996-2005. ICES CM 2006/ C:20. www.ices.dk/ sites/pub/CM\%20Doccuments/2006/C/C2006.pdf

Bersch M (2002) North Atlantic Oscillation-induced changes of the upper layer circulation in the northern North Atlantic Ocean. J Geophys Res 107:3156

* Bersch M, Meincke J, Sy A (1999) Interannual thermohaline changes in the northern North Atlantic 1991-1996. Deep Sea Res II 46:55-75

Bersch M, Yashayaev I, Koltermann KP (2007) Recent changes of the thermohaline circulation in the subpolar North Atlantic. Ocean Dyn 57:223-235

* Burrows MT, Schoeman DS, Richardson AJ, García Molinos J and others (2014) Geographical limits to species-range shifts are suggested by climate velocity. Nature 507: 492-495

Cheung WWL, Lam VWY, Sarmiento JL, Kearney K, Watson R, Pauly D (2009) Projecting global marine biodiversity impacts under climate change scenarios. Fish Fish 10: 235-251

Cheung WWL, Watson R, Pauly D (2013) Signature of ocean warming in global fisheries catch. Nature 497:365-368

Choi JS, Frank KT, Leggett WC, Drinkwater K (2004) Transition to an alternate state in a continental shelf ecosystem. Can J Fish Aquat Sci 61:505-510

Christensen HT, Hedeholm R (2016) Survey for Greenland halibut in ICES Division 14B, August - September 2015. Working document no. 11. Greenland Institute of Natural Resources, ICES NWWG

Cohen D, Inada T, Iwamoto T, Scialabba N (1990) FAO species catalogue Vol 10: Gadiform fishes of the world (Order Gadiformes). An annotated and illustrated catalogue of cods, hakes, grenadiers and other gadiform fishes known to date. FAO, Rome

* Danovaro R, Corinaldesi C, Dell'Anno A, Snelgrove PVR (2017) The deep-sea under global change. Curr Biol 27:R461-R465

* Dickson RR, Brown J (1994) The production of North Atlantic Deep Water: sources, rates, and pathways. J Geophys Res Oceans 99:12319-12341

* Doney SC, Ruckelshaus M, Duffy JE, Barry JP and others (2012) Climate change impacts on marine ecosystems. Annu Rev Mar Sci 4:11-37 
Dufréne M, Legendre P (1997) Species assemblages and indicator species: the need for a flexible asymmetrical approach. Ecol Monogr 67:345-366

Fock HO (2008) Driving-forces for Greenland offshore groundfish assemblages: interplay of climate, ocean productivity and fisheries. J Northwest Atl Fish Sci 39:103-118

Fossheim M, Primicerio R, Johannesen E, Ingvaldsen RB, Aschan MM, Dolgov AV (2015) Recent warming leads to a rapid borealization of fish communities in the Arctic. Nat Clim Change 5:673-677

Frank KT, Petrie B, Shackell NL (2007) The ups and downs of trophic control in continental shelf ecosystems. Trends Ecol Evol 22:236-242

Froese R, Pauly D (2017) FishBase. www.fishbase.org

Gage JD, Tyler PA (1991) Deep-sea biology: a natural history of organisms at the deep-sea floor. Cambridge University Press, Cambridge

* García Molinos J, Halpern BS, Schoeman DS, Brown CJ and others (2016) Climate velocity and the future global redistribution of marine biodiversity. Nat Clim Change 6:83-88

Haedrich RL, Merrett NR (1988) Summary atlas of deep-living demersal fishes in the North Atlantic Basin. J Nat Hist 22:1325-1362

Häkkinen S, Rhines PB (2004) Decline of subpolar North Atlantic circulation during the 1990s. Science 304: 555-559

* Hare JA, Manderson JP, Nye JA, Alexander MA and others (2012) Cusk (Brosme brosme) and climate change: assessing the threat to a candidate marine fish species under the US Endangered Species Act. ICES J Mar Sci 69: 1753-1768

*Hátún H, Chafik L (2018) On the recent ambiguity of the North Atlantic subpolar gyre index. J Geophys Res Oceans 123:5072-5076

* Hátún H, Sandø AB, Drange H, Hansen B, Valdimarsson H (2005) Influence of the Atlantic subpolar gyre on the thermohaline circulation. Science 309:1841-1844

*Hátún H, Payne MR, Beaugrand G, Reid PC and others (2009a) Large bio-geographical shifts in the north-eastern Atlantic Ocean: from the subpolar gyre, via plankton, to blue whiting and pilot whales. Prog Oceanogr 80:149-162

*Hátún H, Payne MR, Jacobsen JA (2009b) The North Atlantic subpolar gyre regulates the spawning distribution of blue whiting (Micromesistius poutassou). Can J Fish Aquat Sci 66:759-770

Hedeholm RB, Mikkelsen JH, Svendsen SM, Carl J, Jensen KT (2017) Atlantic cod (Gadus morhua) diet and the interaction with northern shrimp (Pandalus borealis) in Greenland waters. Polar Biol 40:1335-1346

*Henson SA, Beaulieu C, Ilyina T, John JG and others (2017) Rapid emergence of climate change in environmental drivers of marine ecosystems. Nat Commun 8:14682

Hiddink J, Ter Hofstede R (2008) Climate induced increases in species richness of marine fishes. Glob Change Biol $14: 453-460$

* Hoegh-Guldberg O, Bruno JF (2010) The impact of climate change on the world's marine ecosystems. Science 328: 1523-1528

ICES Advisory Committee (2018) Report of the North Western Working Group (NWWG). ICES CM 2018/ACOM:09. ICES, Copenhagen

Jansen T, Post S, Kristiansen T, Óskarsson GJ and others (2016) Ocean warming expands habitat of a rich natural resource and benefits a national economy. Ecol Appl 26: 2021-2032
Johannesen E, Høines Ås, Dolgov AV, Fossheim M (2012) Demersal fish assemblages and spatial diversity patterns in the Arctic-Atlantic transition zone in the Barents Sea. PLOS ONE 7:e34924

Jones MC, Cheung WW (2015) Multi-model ensemble projections of climate change effects on global marine biodiversity. ICES J Mar Sci 72:741-752

Kerr RA (2000) A North Atlantic climate pacemaker for the centuries. Science 288:1984-1985

*Kingsley MCS, Kanneworff P, Carlsson DM (2004) Buffered random sampling: a sequential inhibited spatial point process applied to sampling in a trawl survey for northern shrimp Pandalus borealis in West Greenland waters. ICES J Mar Sci 61:12-24

Konstantinov K (1970) On the appropriateness of the Flemish Cap cod stock for experimental regulation of a fishery. ICNAF Redbook Part 3:49-55

Kortsch S, Primicerio R, Fossheim M, Dolgov AV, Aschan M (2015) Climate change alters the structure of arctic marine food webs due to poleward shifts of boreal generalists. Proc R Soc B 282:2015.1546

Legendre P, Legendre LF (2012) Numerical ecology, 3rd edn, Vol 24. Elsevier, Amsterdam

Kevin LA, Etter RJ, Rex MA, Gooday AJ and others (2001) Environmental influences on regional deep-sea species diversity. Annu Rev Ecol Syst 32:51-93

Lilly G (1987) Synopsis of research related to recruitment of Atlantic cod (Gadus morhua) and Atlantic redfishes (Sebastes sp.) on Flemish Cap. NAFO Sci Coun Stud 11: 109-122

MacKenzie BR, Payne MR, Boje J, Høyer JL, Siegstad H (2014) A cascade of warming impacts brings bluefin tuna to Greenland waters. Glob Change Biol 20:2484-2491

McCullagh P, Nelder J (1989) Generalized linear models. Chapman and Hall/CRC, Boca Raton, FL

Mecklenburg CW, Lynghammar A, Johannesen E, Byrkjedal I and others (2018) Marine fishes of the Arctic region, Vol 2. Conservation of Arctic Flora and Fauna, Akureyri

Meredith M, Sommerkorn M, Cassotta S, Derksen C and others (2019) Polar regions. In: Pörtner HO, Roberts DC, Masson-Delmotte V, Zhai P and others (eds) IPCC Special Report on the Ocean and Cryosphere in a Changing Climate. IPCC, Geneva, p 203-320 (in press), www.ipcc. ch/site/assets/uploads/sites/3/2019/11/07_SROCC_Ch03 _FINAL.pdf

Møller PR, Nielsen JG, Knudsen SW, Poulsen JY, Sünksen $\mathrm{K}$, Jørgensen OA (2010) A checklist of the fish fauna of Greenland waters. Zootaxa 2378:1-84

Mueter FJ, Litzow MA (2008) Sea ice retreat alters the biogeography of the Bering Sea continental shelf. Ecol Appl 18:309-320

* Mueter FJ, Broms C, Drinkwater KF, Friedland KD and others (2009) Ecosystem responses to recent oceanographic variability in high-latitude Northern Hemisphere ecosystems. Prog Oceanogr 81:93-110

NAFO (2015) Report of the $8^{\text {th }}$ Meeting of the NAFO Scientific Council Working Group on Ecosystem Science and Assessment (WGESA), Dartmouth, NS, Canada

NOAA (2018) Web portal for Climate Time Series of the Earth System Research Laboratory of the National Oceanic and Atmospheric Administration. www.esrl.noaa.gov

Nogueira A, González-Troncoso D, Tolimieri N (2016) Changes and trends in the overexploited fish assemblages of two fishing grounds of the Northwest Atlantic. ICES J Mar Sci 73:345-358 
Nogueira A, Pérez-Rodríguez A, González-Troncoso D, Saborido-Rey F (2018) Could population and community indicators contribute to identify the driver factors and describe the dynamic in the Flemish Cap demersal assemblages? Fish Res 204:33-40

Núñez-Riboni I, Akimova A (2015) Monthly maps of optimally interpolated in situ hydrography in the North Sea from 1948 to 2013. J Mar Syst 151:15-34

Núñez-Riboni I, Akimova A (2017) Quantifying the impact of the major driving mechanisms of inter-annual variability of salinity in the North Sea. Prog Oceanogr 154:25-37

Núñez-Riboni I, Kristinsson K, Bernreuther M, van Aken HM, Stransky C, Cisewski B, Rolskiy A (2013) Impact of interannual changes of large scale circulation and hydrography on the spatial distribution of beaked redfish (Sebastes mentella) in the Irminger Sea. Deep Sea Res I 82:80-94

Nye JA, Link JS, Hare JA, Overholtz WJ (2009) Changing spatial distribution of fish stocks in relation to climate and population size on the Northeast United States continental shelf. Mar Ecol Prog Ser 393:111-129

Oksanen J, Blanchet FG, Friendly M, Kindt R and others (2017) vegan: Community Ecology Package. Version 2.5-6. https://cran.r-project.org/package=vegan

Pace ML, Cole JJ, Carpenter SR, Kitchell JF (1999) Trophic cascades revealed in diverse ecosystems. Trends Ecol Evol 14:483-488

Pauly D, Alder J, Bakun A, Heileman S and others (2005) Marine fisheries systems. Ecosystems and human well-being: current state and trends, Vol 1. Millennium Ecosystem Assessment and Island Press, Washington, DC, p 477-511

Pedchenko AP (2005) The role of interannual environmental variations in the geographic range of spawning and feeding concentrations of redfish Sebastes mentella in the Irminger Sea. ICES J Mar Sci 62:1501-1510

Pereira AM, Jonsson B, Johannsson M, Robalo JI, Almada VC (2012) Icelandic lampreys (Petromyzon marinus): Where do they come from? Ichthyol Res 59:83-85

Pérez-Rodríguez A, Saborido-Rey F (2012) Food consumption of Flemish Cap cod Gadus morhua and redfish Sebastes sp. using generic bioenergetic models. NAFO, Scientific Council Research (SCR) Document 12/68, Rep No. 0256-6915. http://hdl.handle.net/10261/83609

Perry AL, Low PJ, Ellis JR, Reynolds JD (2005) Climate change and distribution shifts in marine fishes. Science 308:1912-1915

Pinsky ML, Worm B, Fogarty MJ, Sarmiento JL, Levin SA (2013) Marine taxa track local climate velocities. Science 341:1239-1242

Post S, Werner KM, Núñez-Riboni I, Chafik L, Hátún $H$, Jansen T (2020) Subpolar gyre and temperature drive boreal fish abundance in Greenland waters. Fish Fish (in press), https://doi.org/10.1111/faf.12512

R Development Core Team (2016) R: a language and environment for statistical computing. Version 3.3.1. R Foundation for Statistical Computing, Vienna

Editorial responsibility: Franz Mueter,

Juneau, Alaska, USA

Reviewed by: 3 anonymous referees
Roberts DW (2016) labdsv: Ordination and Multivariate Analysis for Ecology. https://cran.r-project.org/package =labdsv

Rochet MJ, Collie JS, Trenkel VM (2013) How do fishing and environmental effects propagate among and within functional groups? Bull Mar Sci 89:285-315

* Rutterford LA, Simpson SD, Jennings S, Johnson MP and others (2015) Future fish distributions constrained by depth in warming seas. Nat Clim Change 5:569-573

* Smith CJ, Papadopoulou KN, Diliberto S (2000) Impact of otter trawling on an eastern Mediterranean commercial trawl fishing ground. ICES J Mar Sci 57:1340-1351

* Stefansdottir L, Solmundsson J, Marteinsdottir G, Kristinsson K, Jonasson JP (2010) Groundfish species diversity and assemblage structure in Icelandic waters during recent years of warming. Fish Oceanogr 19:42-62

Stocker TF, Qin D, Plattner GK, Tignor M and others (eds) (2013) Climate change 2013. The physical science basis. Cambridge University Press, Cambridge

* Sutherland DA, Pickart RS (2008) The East Greenland Coastal Current: structure, variability, and forcing. Prog Oceanogr 78:58-77

* Ter Hofstede R, Hiddink JG, Rijnsdorp AD (2010) Regional warming changes fish species richness in the eastern North Atlantic Ocean. Mar Ecol Prog Ser 414:1-9

*Våge K, Pickart RS, Sarafanov A, Knutsen $\varnothing$ and others (2011) The Irminger Gyre: circulation, convection, and interannual variability. Deep Sea Res I 58:590-614

* van Aken HM, de Jong MF, Yashayaev I (2011) Decadal and multi-decadal variability of Labrador Sea Water in the north-western North Atlantic Ocean derived from tracer distributions: heat budget, ventilation, and advection. Deep Sea Res I 58:505-523

* von Appen WJ, Koszalka IM, Pickart RS, Haine TWN and others (2014) The East Greenland Spill Jet as an important component of the Atlantic meridional overturning circulation. Deep Sea Res I 92:75-84

* Wassmann P (2011) Arctic marine ecosystems in an era of rapid climate change. Prog Oceanogr 90:1-17

*Westgaard JI, Saha A, Kent M, Hansen HH and others (2017) Genetic population structure in Greenland halibut (Reinhardtius hippoglossoides) and its relevance to fishery management. Can J Fish Aquat Sci 74: 475-485

Wood SN (2017) Generalized additive models: an introduction with R, 2nd edn. Chapman and Hall/CRC, Boca Raton, FL

WWorm B, Myers RA (2003) Meta-analysis of cod-shrimp interactions reveals top-down control in oceanic food webs. Ecology 84:162-173

* Worm B, Hilborn R, Baum JK, Branch TA and others (2009) Rebuilding global fisheries. Science 325:578-585

*Yasuhara M, Danovaro R (2016) Temperature impacts on deep-sea biodiversity. Biol Rev Camb Philos Soc 91: $275-287$

Submitted: January 15, 2020

Accepted: September 8, 2020

Proofs received from author(s): October 28, 2020 